\title{
Silage Additives: Review
}

\author{
Melkamu Bezabih Yitbarek ${ }^{1}$, Birhan Tamir ${ }^{2}$ \\ ${ }^{1}$ Department of Animal Science, College of Agriculture and Natural Resources, Debre Markos University, \\ Debre Markos, Ethiopia \\ ${ }^{2}$ College of Veterinary Medicine and Agriculture, Addis Ababa University, Addis Ababa, Ethiopia \\ Email: melkamu_bezabihy@yahoo.com
}

Received 3 March 2014; revised 5 April 2014; accepted 12 April 2014

Copyright (C) 2014 by authors and Scientific Research Publishing Inc.

This work is licensed under the Creative Commons Attribution International License (CC BY). http://creativecommons.org/licenses/by/4.0/

(c) (i) Open Access

\begin{abstract}
Silage making process can be explained very simply, it is actually very complex and dependant on many factors, such as the natural microbial population, harvesting conditions and the sugar content of the forage. Consequently, silage quality can be very variable and the only way to effectively control the fermentation process is to use an additive. Additives are natural or industrial products added in rather large quantities to the forage or grain mass. Additives control or prevent certain types of fermentation, thus reducing losses and improving silage stability. In order to assist in the fermentation process, various silage additives have been used to improve the nutrient and energy recovery in silage, often with subsequent improvements in animal performance. The purpose for applying additives to the silage is to ensure that the growth of lactic bacteria predominates during the fermentation process, producing lactic acid in quantities high enough to ensure good silage. Therefore this review is made to focus on some practical aspects of the fermentation process and the uses of some common silage additives that include microbial inoculants, enzymes, and propionic acid.
\end{abstract}

\section{Keywords}

Silage, Silage Additives, Fermentation, Inoculants

\section{Introduction}

Considering the real climate conditions, silage is the best method for preserving fresh forage with minimal losses. Silage quality and nutritional value are influenced by numerous biological and technological factors, when the proper ensilage techniques are used, silage will have a high nutritive value and hygienic quality [1]. However, the results in practice indicate that the quality of silage is often poor or even unsatisfactory. These results are usually achieved when the fermentation condition are difficult [2] Factors which influence fermentation includes 
degree of green fodder wilting, length of cut, ensiling technology type, and amount of an additive used [3].

Silage additives are natural or industrial products added in rather large quantities to the forage or grain mass. The purpose of silage additives is to control the preservation process so that by the time of feeding it has retained as many of the nutrients present in the original fresh forage as possible and to ensure that the growth of lactic bacteria predominates during the fermentation process, producing lactic acid in quantities high enough to ensure a good silage [4]. Additives are used to improve nutrient composition of silage, to reduce storage losses by promoting rapid fermentation, to reduce fermentation losses by limiting extent of fermentation, and to improve bunk life of silage (increase aerobic stability). It is widely accepted that silage additives can increase animal intake and animal performance through their effect on silage quality [5]. However, the exact nutrient status of the silage will depend on many factors that can only be controlled via management. It is important to remember that silage additives will not make poor quality forage into good silage but they can help make top quality forage into excellent quality silage [6]. Many different silage additives are available and are used for different reasons. It includes fermentation stimulants, fermentation inhibitors, aerobic deterioration inhibitors, nutrients and absorbents [7]. Their main functions are to either increase nutritional value of silage or improve fermentation so that storage losses are reduced.

Based on the above information, different authors described about the purpose of Silage additives that can be used to ensure silage quality by encouraging lactic acid fermentation, by inhibiting undesirable microbes or by improving its nutritional value. Therefore to know and understand more about the use of silage additives this review is made from different sources.

\section{Literature Review}

\subsection{Silage and Principles of Ensiling}

\subsubsection{Silage}

Silage can be defined as any plant material that has undergone fermentation or "pickling" in a silo. And a silo is any storage structure in which green, moist forage is preserved [8]. The primary goal of making silage is to maximize the preservation of original nutrients in the forage crop for feeding of livestock at a later date in livestock feeding programs [8].

\subsubsection{Principles of Ensiling}

Ensilage or ensiling is a process of preserving forage for later use as animal feed [8]. The principles of ensilage are well known. The first essential objective is to achieve anaerobic conditions under which natural fermentation can take place. In practice this is achieved by consolidating and compacting the material and the sealing of the silo to prevent re-entry of air. Air that is trapped in the herbage is rapidly removed by respiratory enzymes [7]. Where oxygen is in contact with herbage for a period of time, aerobic microbial activity occurs and yeast and mould will grow. This causes the material to decay to a useless, inedible and frequently toxic product [7]. Finer chopping of plant material results in improved compaction and fermentation of silage. This then improves palatability and intake of silage [9].

The second objective is to discourage the activities of undesirable microorganisms such as clostridia and enterobacteria. Clostridia are present on crops and in the soil in the form of spores. Clostridia multiply under anaerobic conditions, produce butyric acid and break down amino acids resulting in silage with a poor palatability and lower nutritional value. The enterobacteria are no-spore forming, facultative anaerobes, which ferment sugars to acetic acid and other products. Enterobacteria also have the ability to degrade amino acids [7]. Growth of clostridia and enterobacteria can be inhibited by lactic acid fermentation. Lactic acid bacteria are normally present on harvested crops and these organisms ferment naturally occurring sugars like glucose and fructose to mainly lactic acid. The lactic acid produced increases the hydrogen ion concentration and undissociated acids to a level at which undesirable organisms are inhibited [7]. The critical $\mathrm{pH}$ at which growth of clostridia and enterobacteria are inhibited depends on the moisture content and the temperature. The wetter the material the lower the critical $\mathrm{pH}$ will be. According to [10] the $\mathrm{pH}$ required for stability of silage at 150, 250, 350 and $450 \mathrm{~g}$ $\mathrm{DM} / \mathrm{kg}$, is 4.10, 4.35, 4.60 and 4.85 respectively. The growth of most acid tolerant clostridia will be inhibited by a pH just below 5.0 [11]. With very wet crops at a DM concentration of $150 \mathrm{~g} / \mathrm{kg}$ even a pH of 4 may not inhibit clostridial growth. Clostridia are very sensitive to water availability and require wet conditions for active development. Growth of clostridia can be inhibited by reducing the moisture content by wilting prior to ensiling. Lac- 
tic acid bacteria have a high tolerance to low moisture conditions and are able to dominate the fermentation of high dry matter crops [7].

Lactic acid bacteria, which are the most important species during ensiling, are usually present on grass in numbers 1000 times lower than their main competitors, fungi and enterobacteria. After ensiling, the microorganisms capable of anaerobic growth namely, lactic acid bacteria, enterobacteria, clostridia, some Bacillus spp. and yeasts begin to grow and compete for available nutrients. The first few days of ensiling are critical to the success or failure of the subsequent fermentation. Under favourable conditions lactic acid bacteria will quickly acidify the environment to such an extent that the competing organisms will not be able to survive and the end result will be a stable, low $\mathrm{pH}$ silage. If, however, the $\mathrm{pH}$ is not lowered quickly enough the undesirable microorganisms, mainly enterobacteria, clostridia and yeasts will be able to compete for nutrients. This will reduce the chances of obtaining a stable silage [7].

Many investigations have been performed on the numbers of epiphytic bacteria on silage crops. Numbers of epiphytic bacteria found on standing grass and Lucerne [12] are often below 100/g of fresh material. The numbers present on the crop at ensiling are of more practical importance. After mowing, wilting and chopping increased numbers of epiphytic lactic acid bacteria are found. The numbers at ensiling range from 50,000 to 500,000 with extremes up to 10 million/g [13]-[16].

Wilting of crops is often recommended. [17] found that only $10 \%$ of the total epiphytic lactic acid bacteria on grasses can grow at a dry matter content of above $450 \mathrm{~g} / \mathrm{kg}$. Climatic conditions do have an impact on the numbers of viable lactic acid bacteria. High numbers at ensiling positively correlate with environmental temperature and air humidity and negatively with solar radiation [14] [18]. [14] reported on a survey of 991 grass and 370 maize crops samples and found $46 \%$ to $59 \%$ of the lactic acid bacteria were homofermentative. By increasing the number of homofermentative lactic acid bacteria more efficient fermentation may take place.

\subsection{Silage Additives}

Silage fermentation is a dynamic process that is affected by variety of factors. Research on silage and silage additives has been conducted for many years to improve the nutritive value of silages and to reduce some of the risks during the ensiling process [19]. A silage additive should be safe to handle, reduce DM losses, Silage additives are added to the forage or crop at ensiling, may improve the ensiling (fermentation) process, reduce losses, reduce aerobic deterioration at feedout, improve the hygienic quality of the silage, limit secondary fermentation, improve aerobic stability, increase the nutritive value of the silage, as the result increase animal production and give the farmer a return greater than the cost of the additive [20]. Some silage additives may also reduce unavoidable losses particularly those associated with the plant enzymes and microorganism or field losses. Examples of the five main classes of silage additives are fermentation stimulants (bacteria culture and carbohydrate sources), fermentation inhibitors (acids, formaldehyde etc.), aerobic deterioration inhibitors (lactic acid bacteria, propionic acid etc.), nutrients (urea, ammonia etc.) and absorbents (barley, straw etc.) [7].

According to [21], there are five types of Silage Additives such as

1) Fermentation stimulants:

a) Fermentable carbohydrates Sugar sources such as Molasses, sucrose, glucose, citrus pulp, pineapple pulp, sugar beet pulp

b) Enzymes like Cellulases, hemicellulases, amylases

c) Inoculants such as Lactic acid bacteria (LAB)

2) Fermentation inhibitors:

a) Acids and organic acid salts such as Mineral acids (e.g. hydrochloric), formic acid, acetic acid, lactic acid, acrylic acid, calcium formate, propionic acid, propionates

b) Other chemical inhibitors such as Formaldehyde, sodium nitrite, sodium metabisulphite

3) Aerobic spoilage inhibitors:

Like Propionic acid, propionates, acetic acid, caproic acid, ammonia, some inoculants

4) Nutrients

Like Urea, ammonia, grain, minerals, sugar beet pulp

5) Absorbents

Like Grain, straw, bentonite, sugar beet pulp, polyacrylamide

In order to improve crop preservation and its feeding value, common silage additives are described below. 


\subsubsection{Biological Additives}

Microbial inoculants and enzyme preparations are regarded as natural products which are safe to handle, noncorrosive to machinery, do not cause environmental problems and their usage has expanded remarkably in the last decades. Perhaps no other area of silage management has received as much attention among both researchers and livestock producers as bacterial inoculants [22]. There are many commercial products with variable efficacy available. However, dosage and method of application are decisive for effectiveness.

\section{1) Microbial Inoculation}

a) Organisms

Inoculants are added to silage to dominate the epiphytic (natural) population of bacteria on plants that cause DM losses by inefficient fermentation of sugars. The three main types of microbial inoculants are 1) homofermentive; 2) homolactic; and 3) heterofermentive. Homofermentative inoculants contain bacteria such as Lactobacillus plantarum, Pediococcus and Lactococcus species. They promote a rapid fermentation producing mainly lactic acid and bring the $\mathrm{pH}$ down to 4 rapidly, preventing further breakdown of the sugar and protein in the crop. Heterofermentative inoculants-contain bacteria such as Lactobacillus buchneri and Lactobacillus brevis. They produce a mix of lactic and acetic acid which results in a slower fermentation than the homofermentative inoculants. They are designed to inhibit yeast and moulds that initiate the process of aerobic deterioration during feedout [6].

Forage often naturally contains many detrimental types of bacteria, the concept of adding a microbial inoculant to silage was to add fast growing homofermentative lactic acid bacteria (hoLAB) in order to dominate the fermentation resulting in a higher quality silage. Some of the more common homolactic acid bacteria (hoLAB) used in silage inoculants include Lactobacillus plantarum, L. acidophilus, Pediococcus acidilactici, P. pentacaceus, and Enterococcus faecium. Microbial inoculants contain one or more of these bacteria which have been selected for their ability to dominate the fermentation. The rationale for multiple organisms comes from potential synergistic actions. For example, growth rate is faster in Enterococcus > Pediococcus > Lactobacillus. Some Pediococcus strains are more tolerant of high DM conditions than are Lactobacillus and have a wider range of optimal temperature and $\mathrm{pH}$ for growth (they grow better in cool conditions found in late fall and early Spring [23].

In Europe and the USA bacterial inoculants have nowadays become the most commonly used additives for corn, and grasses and legumes that can be wilted to above $300 \mathrm{~g} \mathrm{DM} \mathrm{kg}^{-1}$ [17] [22] [24] [25].

b) Fermentation and Animal Response

The selection of the right biological silage additive will be made taking into account some rules. The amount of water-soluble carbohydrates necessary to obtain sufficient fermentation depends on the dry matter content and the buffer capacity of the crop. [10] characterized the relation between these factors as follows,

$\mathrm{FC}=\mathrm{DM}(\%)+8 \mathrm{WSC}$ (sugar content)/BC

$\mathrm{FC}=$ fermentation coefficient

$\mathrm{DM}=$ dry matter content

WSC $=$ water-soluble carbohydrates

$\mathrm{BC}=$ buffer capacity

- If FC $<35$ = bad ensilable

- If FC between 35 and 45 i.e. $35<\mathrm{FC}<45$ = middle ensilable

- If FC > 45 = good ensilable

Forages with insufficient fermentable substrate or too low a dry matter content have a $\mathrm{FC}<35$. In these forages sufficient fermentation can only be achieved if the sugar content of the material is increased, either by adding sugars directly (e.g. molasses) or by adding enzymes that release extra sugars from the crop. In forages with a FC of 35 or more sufficient fermentable substrate is available. Also, adding suitable lactic acid bacteria can accelerate and improve the ensiling process. In high dry matter silages with reduced water availability the presence of suitable, osmotolerant lactic acid bacteria could become a limiting factor in the ensiling process. It has been shown that these bacteria represent only a small percentage of the indigenous microflora on forage crops [17]. Forages with dry matter content above 50\% are considered difficult to ensile [26].

The formula of [10] does not apply for crops with a low nitrate content such as extensively managed grasses and immature whole crop cereals, because these crops are more liable to clostridial fermentations than crops with a moderate nitrate content [27]. Inoculants that increase lactic acid fermentation might be useful to inhibit clostridial activity. The minimum number of lactic acid bacteria required to inhibit clostridial activity was found 
to be at least 100,000 colony forming units per gram of fresh crop [10] [28].

Lactic and acetic acids are major components of fermentation that are responsible for the increase in acidity of ensiled biomass [29]. In the present study, silages treated with lactic acid bacteria resulted in highest amount of organic acids and lowering final $\mathrm{pH}$ value improved the qualitative parameters of the silage compared with control. The silages treated with biological additives had also lower cell wall components (NDF, ADF) than silages control. Alfalfa, grass, and small cereal grain crops have responded well to microbial inoculation with hoLAB. The fermentation of high moisture corn has also been improved with hoLAB. A study conducted in North America where corn silage was treated with a hoLAB microbial inoculant; there was a significant improvement in animal performance and a small change in fermentation end products. [30] reported that in 19 studies conducted at Kansas State University, with corn silage, silages inoculated with hoLAB had 1.3 percentage unit higher DM recovery, supported 1.8\% more efficient gains, and produced $3.6 \mathrm{lb}$ more gain per ton of crop ensiled with beef cattle. Similar results were found with treated sorghum silages. In certain instances, significant animal responses have been observed with inoculation although there was little effect on traditional end products of fermentation [31] [32]. These data suggest that lack of detectable changes in classically measured fermentation end products is not a good indicator of the effectiveness of an inoculant.

When compared to untreated silages, silages treated with adequate numbers of a viable hoLAB should be lower in $\mathrm{pH}$, acetic acid, butyric acid and ammonia-N but higher in lactic acid content. [25] reported that microbial inoculation lowered $\mathrm{pH}$, improved the lactic: acetic ratio, and lowered ammonia nitrogen content in more than $60 \%$ of studies. Dry matter recovery was improved in 35\% of the studies. Dry matter digestibility was also improved in about one third of the cases. Microbial inoculation usually has little or no effect on the fiber content of silages because most lactic acid bacteria contain little or no ability to degrade plant cell walls. Decreases in fiber content may be due to partial acid hydrolysis of hemicellulose. Some data suggests that certain microbial inoculants can increase fiber digestion [33]. Bunk life or aerobic stability was improved in only $33 \%$ of the studies and in fact inoculation with hoLAB has, in many instances, made aerobic stability worse. This is probably due to a lower content of acetic acid and other potential antifungal end products. Silage treated with hoLAB can be extremely stable if feeding and silo management is good.

Relative to animal responses, [24] reported positive responses to microbial inoculants on intake, gain, and milk production (Table 1). The average response in milk production was a $+3.1 \mathrm{lb}$ per day in studies where milk production was statistically improved. A summary of 14 lactation studies conducted in University and government research institutes in North America and Europe using resulted in an average increase of 4.6\% [34]. Improvements in milk yield were obtained with a variety of crops (grass, corn, and alfalfa) across a wide spectrum of DM contents (15\% to $46 \%$ DM). The study of [35] did show an improvement in aerobic stability, higher silage intake, less protein breakdown in maize silage when an inoculant was added during ensiling. Milk production was, however, not increased. The intake of lambs fed inoculated maize silage was $10.7 \%$ higher and growth tended to be $6.6 \%$ higher [36]. The adding of an inoculant to oat silage made at soft dough stage did result in improved preservation, higher intake $(+5.1 \%)$ and a milk response of $1 \mathrm{~kg} /$ day $(+5.9 \%)$ in Jersey cows [9].

Similarly, 19 comparisons among untreated silages [34] summarized silages treated with MTD1 for beef cattle. Across all studies and types of forage, cattle fed inoculated silage inoculated with MTD1 ate 7.5\% more DM and gained $11.1 \%$ more weight. Unfortunately, there is no good way to predict the effectiveness of microbial inoculants. A model developed by [37] suggested that inoculants would be most effective on alfalfa during cool conditions of first, third and fourth cuttings. However, there are numerous products that have little or no research to support claims of improved fermentation or animal performance. Another factor which complicates the evaluating process is that the majority of bacterial inoculants are repackaged for distribution under private label and numbers of bacteria may be low and/or other additives (e.g., enzymes, fermentation extracts, minerals) are included in the formulations.

c) Inoculation Rate, Use, and Storage

The organism(s) from microbial inoculants must be present in sufficient numbers to effectively dominate the fermentation. The most commonly recommended inoculation rate for $L$. plantarum based-inoculant results in a final concentration of 100,000 (or $1 \times 10^{5}$ ) colony forming units of this organism per gram of wet forage. There is limited evidence to support the suggestion of some that doubling or tripling this amount (e.g. 200,000 $300,000 \mathrm{cfu})$ is more beneficial. Additions of 1,000,000 $\left(1 \times 10^{6}\right)$ cfu per gram of wet forage are probably not cost effective in North America [23].

According to a study of [23] most microbial inoculants are available in powder or granular form. Inoculants 
Table 1. The effect of inoculant on silage fermentation, aerobic stability, intake, growth and milk production.

\begin{tabular}{|c|c|c|c|c|c|c|}
\hline Crop & Fermentation & Aerobic stability & Intake & Growth & Milk prod & Author \\
\hline D.eriantha & +++ & +++ & +++ & ND & ND & [38] \\
\hline E.curvula & +++ & 0 & ND & ND & ND & [39] \\
\hline Ryegrass & +++ & ND & ++ & ++ & +++ & [40] \\
\hline Ryegrass & +++ & ND & ND & ND & ND & [5] \\
\hline Ryegrass & 0 & ND & 0 & 0 & 0 & [41] \\
\hline Ryegrass & 0 & 0 & ++ & + & +++ & [30] \\
\hline Ryegrass & 0 & ND & 0 & ND & 0 & [42] \\
\hline Maize & + & ND & ++ & ++ & ++ & [43] \\
\hline Maize & + & ND & + & ++ & ND & [44] \\
\hline Maize & 0 & 0 & +++ & + & ND & [36] \\
\hline Maize & 0 & ++ & +++ & 0 & 0 & [35] \\
\hline Maize & +++ & 0 & 0 & 0 & ND & [45] \\
\hline Maize & ND & ND & ++++ & 0 & +++ & [46] \\
\hline Maize & + & --- & ND & ND & ND & [47] \\
\hline Oats & +++ & 0 & +++ & 0 & +++ & [48] \\
\hline Wheat & +++ & --- & ND & ND & ND & [49] \\
\hline Sorghum & +++ & --- & ND & ND & ND & [50] \\
\hline Lucerne & +++ & 0 & ND & ND & ND & [51] \\
\hline Lucerne & +++ & 0 & ND & ND & ND & [52] \\
\hline
\end{tabular}

$+++=$ large positive effect, ++ = medium positive effect, $+=$ slight positive effect, $0=$ no effect, --- = negative effect, $\mathrm{ND}=$ not determined.

applied in the dry form are often mixed with calcium carbonate (limestone), dried skim milk, sucrose or other carriers. These products can be applied by hand or by solid metering devices as per manufacturer's recommendations. Inoculants to be applied in the liquid form come as dried powders and are mixed with water just prior to use. Use of chlorinated water may be detrimental to the inoculant if levels exceed more than 1.5 to 2 PPM. Application can be with a simple watering can by weighing the incoming forage load and adjusting application based on the average unloading time. A better method is to use a metered liquid sprayer to evenly disperse the inoculant on the forage. Unused liquids should be discarded after a period of 24 to $48 \mathrm{~h}$ because bacterial numbers begin to decline.

Microbial inoculants can be applied to the forage at a variety of locations. However, application to forage at the chopper is highly recommended in order to maximize the time that microorganisms have in contact with fermentable substrates. Application at the chopper is more important if silage is being stored in a bunk or pile because it is difficult to achieve good distribution onto silage from a forage wagon. Distribution of the inoculant is less of a problem if it is applied at the blower of an upright silo or at the bagger. Throwing a can of dry inoculant onto a load of forage and hoping for even distribution is not an acceptable practice. Inoculants can be applied in a liquid or solid form. [53] reported that on higher DM silages (greater than about 45\% DM), using a liquid based inoculant is preferable because the low moisture in these silages limits fermentation. Inoculants applied in a liquid form may be more advantageous because the bacteria are added with their own moisture to help speed up fermentation.

Storage is an important aspect of a high quality inoculant that contains live microorganisms. Some inoculants require refrigeration or freezing for optimum storage. Those that do not require cold temperatures for storage should still be kept in cool, dry areas away from direct sunlight. Moisture, oxygen and sunlight can decrease the 
stability of inoculants resulting in lower viable counts and a product that does not meet label guarantees [23]. Opened bags of inoculants should be used as soon as possible and, if not completely used, probably not carried over into the next season.

d) Miscellaneous Organisms

Several microorganisms that are not hoLAB have been used as silage inoculants specifically for the purpose of improving aerobic stability. For example, the Propionibacteria are able to convert lactic acid and glucose to acetic and propionic acids that are more antifungal than lactic acid. [54] reported that addition of $P$. shermanii prevented the growth of molds and markedly reduced the initial population of yeast in high moisture corn where the final $\mathrm{pH}$ was greater than 4.5. [55] reported similar findings in high moisture corn. [49] saw little benefit from adding Propionibacteria to pearl millet and corn silage (final $\mathrm{pH}<4.0$ ) but reported improvements in the aerobic stability of wheat silage when the decline in $\mathrm{pH}$ was slow. Studies conducted in laboratory silos, there was no observed beneficial effects of Propionibacteria in corn silage (final pH 3.6 to 3.8) [56]. However, [22] reported more propionic acid, lower yeasts and molds, and greater aerobic stability in corn silage (pH of 3.6) treated with Propionibacteria. Some concerns relative to the use of Propionibacteria that have not been adequately addressed are the loss of DM (from $\mathrm{CO}_{2}$ production) and the fact that Propionibacteria have proteolytic activity. The primary reasons for the ineffectiveness of these organisms include the facts that they are strict anaerobes, they are slow growing, and they are relatively acid intolerant.

Heterolactic lactobacilli may also be useful as silage inoculants. For example, two new isolated heterolactic strains of Lactobacillus plantarum have been shown to improve the aerobic stability of corn silage by an average of 28 hours in five studies [57]. These organisms where selected for fast growth, production of lactic and acetic acids, and the ability to suppress the growth of 5 major strains of yeasts that cause spoilage in corn silage. Another heterolactic acid bacteria having potential to improve the aerobic stability of silages are Lactobacillus buchneri. [58] reported that corn silage treated with $L$. buchneri was more stable than untreated silage. They suggest that improved aerobic stability was due to the ability of $L$. buchneri to ferment lactic acid to acetic acid and 1,2 propanediol [59]. [60] added L. buchneri to corn silage at a rate of $10^{3}$ to $10^{6} \mathrm{cfu} / \mathrm{g}$ of silage and found decreased numbers of yeasts in silage and increased acetic acid in silage (from 1.8\% to 3.6\%, DMB).

Aerobic stability was markedly improved by inoculation (control silage heated after 26 hours while treated silages remained cool for more than $400 \mathrm{~h}$ in silage). Increases in acetic and propionic acids in silages treated with $L$. buchneri accompanied improvements in the aerobic stability of barley silage [32]. We also have observed improved aerobic stability in high moisture corn treated with L. buchneri [32]. In addition, high levels of acetic acid may depress animal intakes. To date, in research studies, losses of DM have been small and no negative effects on animal performance have been observed when feeding silages treated with $L$. buchneri [23].

\section{2) Enzyme Additives}

The possibilities of using enzymes help to improve nutrient digestion, utilization, and animal productivity and at the same time reduce animal fecal material and pollution. Spraying enzymes onto forages just before feeding provides increased management flexibility for feeding and also bypasses any negative interactions that the ensiling process may have on silage enzyme performance. When enzymes are sprayed onto silage before feeding, binding with substrates may help to protect these exogenous enzymes from ruminal degradation. Treating forages with enzymes in this manner may improve digestibility via a number of different mechanisms that including, direct hydrolysis, improvements in palatability, changes in gut viscosity, and changes in the site of digestion [23].

The enzyme amylase is useful for degrading starch into sugars. Cellulases or xylanases degrade cell walls into sugars. Sugars released by the enzymes increase growth of silage bacteria and, in some cases, fiber degrading enzymes also increase forage digestibility. These enzymes usually are most effective on low-lignin feedstuffs such as cereal silages and immature, cool-season grasses. Fiber-digesting enzymes have been most effective in reducing the fiber content of grass and alfalfa crops ensiled in the $60 \%$ to $70 \%$ moisture range [25] the effect being greatest in grasses. Improvements in silage fermentation and decreases in fiber content appear more pronounced in immature grasses than mature grasses where hydrolysis of the cell wall would be more difficult due to increased lignification. Enzymes have improved fermentation by stimulating acid production, lowering pH, and lowering ammonia N. Results of enzymes on DM or fiber digestion have been more negative than positive. A possible reason for this is that fiber-degrading enzymes predigest the readily digestible fiber leaving a slower and less degradable fraction [23].

[25] found that positive responses in intake, gain and milk production were less for silages treated with en- 
zymes than with microbial inoculants. There are many variables that may affect the efficacy of fiber-degrading enzymes. Just as bacterial inoculants require certain conditions for growth, enzymes require certain conditions for maximum activity. Most cellulase enzymes require a $\mathrm{pH}$ of 4.5 and temperature of $50^{\circ} \mathrm{C}$ for optimal activity. Surface area, binding sites, moisture level and plant proteases may also inhibit enzyme activity. We also do not know the optimum mixture of enzymes that will improve silage fermentation. For example, "cellulose" enzymes are a complex of various endo- and exo-beta-glucanases, cellobiohydrolase, and cellobiase. [61] who reported that cellulase enzymes addition was capable to breakdown the component of structural carbohydrates during ensiling and improving fiber degradation during silage fermentation. Much research has shown an improvement in cell wall degradation by enzyme inclusion during silage fermentation [62]. It might be due to more substrate of fermentable carbohydrates were provide from the hydrolysis of cellwall components, which stimulate a good fermentation by lactic acid bacteria. Complete breakdown of insoluble cellulose to glucose requires synergistic action between the enzymes.

Spraying enzymes on the silage has increased the release of residual sugars and rate of NDF digestion. A mixture of fiber degrading enzymes sprayed onto the forage portion of a total mixed ration resulted in cows consuming $4 \mathrm{lb}$ more DM per day and producing $2.8 \mathrm{lb}$ more milk per day [63]. Maine researchers reported that dry matter intake increased by $10.7 \%$ and milk yield by $14.7 \%$ in one study [64]. However, [65] reported that the growth of Holstein heifers was not improved by application of fiber-degrading enzymes to the silage of a total mixed ration immediately before feeding. [61] reported marked improvements in milk production when an alfalfa hay, alfalfa silage, and cottonseed mix was sprayed with a moderate but not with a lower or higher amount of fiber degrading enzymes. Positive responses to treating the forage portion (primarily corn silage) of a TMR with enzymes in 3 consecutive years have also been observed [24].

\subsubsection{Feed Ingredients and By-Products as Additives}

According to the report of [66] the incorporation of easily fermentable feed ingredients such as sugar or molasses to low DM sugar-limited tropical forages is a way to improve silage fermentation. Feed-grade products such as grains in general and processed by-products such as corn or sorghum meal, rice bran, cassava meal, citrus pulp, etc. can also be used as additives partly to provide fermentable substrate but also to direct the course of fermentation by absorbing excessive moisture. To optimize their effectiveness by avoiding effluent losses they have to be used in relatively high rates (aiming a DM content $>25 \%$ of the mixture) and adequately mixed with the chopped forage, which demands extra labour and/or appropriate equipment. This type of additive may be of seasonal and local supply and cost effectiveness should also consider the improvement achieved in nutritive value.

\section{1) Grain}

According to the report of [66] addition of grain to corn silage is not useful, but adding it to hay crop silage has two benefits. First, adding grain to hay crop silage increases the energy content of the silage. This will reduce the amount of supplemental grain that has to be fed. If silage will be the main or only feed offered, then adding some grain to the forage at ensiling will make it a more complete feed. However, grain mixed with silage prior to ensiling or at feeding is nutritionally equal; therefore, if supplemental grain must be fed anyway, no true benefit is realized. Secondly, adding grain to forage will increase the dry matter content of the silage. Hay crops that are not wilted sufficiently prior to ensiling can cause seepage and result in an undesirable fermentation. Added grain may also make wet silage easier to unload from the silo. Recommended application rate for grain is 100 - $200 \mathrm{lbs} /$ wet ton. This rate will increase the dry matter content of silage by about 5 percentage units. The grain should be cracked or rolled prior to ensiling for maximum benefit. In general, adding grain does not improve fermentation because starch (the main carbohydrate in grain) is not readily fermented in the silo.

\section{2) Molasses}

Cane molasses (75\% DM) has been widely used added up to $10 \% \mathrm{w} / \mathrm{w}$ to provide fast fermentable carbohydrate for the ensilage of tropical herbages. Due to its viscosity it is difficult to apply and should be diluted preferably with a reduced volume of warm water to minimize seepage losses. When applied to tropical grasses molasses should be used in relatively high concentrations ( $4 \%$ to $5 \%$ ) and with crops of very low DM content, a considerable proportion of the additive may be lost in the effluent during the first days of ensilage [19]. However, according to [67] the provision of extraneous sugar alone is not sufficient to permit the lactic acid bacteria to compete with other components of the silage microflora and thus ensure preservation. So, under high moisture conditions molasses can also induce a clostridial spoilage especially with forages contaminated with soil. 
Molasses in numerous silage experiments has been proven to be an effective silage additive in terms of promoting lactic fermentation, reducing silage $\mathrm{pH}$, discouraging a clostridial fermentation and proteolysis, and generally decreasing organic matter losses. It is of particular benefit when applied to forage crops low in fermentable carbohydrates for lactobacilli. Recently, [68] reviewed the published literature on molasses as silage additives and concluded that molasses treatment improved silage preservation, but did not significantly alter the silage digestibility or animal performance although silage DM intake was improved.

Sugarcane molasses added at the rate of 3\% (w/w, fresh basis) to Napier grass (12.9\% DM, 6.6\% WSC) produced silages of reasonably good fermentation quality, however, the nutrient recovery from the silo was reduced as compared to formic acid treated silage [69]. The same molasses dosses also resulted in increased in vitro DM digestibility coefficients of Napier grass ensiled at 51, 96 and 121 days of vegetative growth [70].

Dwarf elephant grass cut at 72 days regrowth (14.4\% DM, 7.1\% WSC) with a high buffering capacity was treated with $4 \%$ molasses and ensiled in $4 \mathrm{~kg}$ polythene bags with the resulting silage having lower $\mathrm{pH}$ and ammonia- $\mathrm{N}$ than the control silage [71].

Four levels $(0 \%, 4 \%, 8 \%$, and $12 \%)$ of dried molasses (97\% DM) were applied to chopped Bermuda grass (32.4\% DM, 70.2\% NDF) pre-treated with 1174 Pioneer silage inoculant (1.7 l/t of forage) and packed in 19-liter plastic containers. The increasing molasses levels lowered $\mathrm{pH}, \mathrm{ADF}$, and NDF percentages and increased in vitro DM digestibilities in Bermuda grass silages [72].

Guinea grass with 4 weeks (18.6\% DM) and 8 weeks (26.5\% DM) of growth was ensiled untreated or with $4 \%$ molasses in $400 \mathrm{~g}$ laboratory silos. The $\mathrm{pH}$ varied from 4.4 to 5.4 and from 4.0 to 4.7 and ammonia-N ranged from 23.5 to 35.3 and from 15 to 39, respectively, for untreated and molasses treated silages [73].

Tjandraatmadja et al. (1994) tested the effects of $4 \%$ and $8 \%$ molasses added at the ensilage of Panicum maximum cv. Hamil, pangola grass (Digitaria decumbens) and setaria (Setaria sphacelata cv. Kazungula) harvested at 4, 8 and 12 weeks of growth. The results from a laboratory trial with 500 g-vacuum sealed silo bags kept in a dark, temperature controlled room led to the conclusion that $4 \%(w / w)$ molasses should be sufficient to achieve effective preservation. Pangola grass which had a highly significant different chemical composition prior to ensiling, with lower NDF and lignin content presented a dominant homo-fermentative lactic acid bacteria population in silage which was fairly well preserved even without molasses.

The effects of adding molasses $(5 \% \mathrm{w} / \mathrm{w})$ or ground maize $(5 \%$ and $10 \% \mathrm{w} / \mathrm{w})$ to star grass (Cynodon nlemfluensis) mixed with four levels $(0 \%, 15 \%, 30 \%, 45 \%$ w/w) of legume (Desmodium uncinatum) were studied in a laboratory trial by [74]. In general, both additives improved fermentation up to the level of $30 \%$ of legume inclusion, however, molasses addition resulted in lower levels of volatile $\mathrm{N}$ and higher lactic acid content compared to the control and both ground maize treatments.

\section{3) Starch Sources}

It is controversial to what extent starch is an available substrate for lactic acid bacteria [67]. [75] recovered $100 \%$ and $90 \%$ of starch from barley and oats, respectively, added at the ensilage of ryegrass, attributing an improved fermentation to the substrate available from $3 \%-4 \%$ of soluble carbohydrates or from fractions such as $\beta$-glucan contained in the cereals and not to a hydrolysis of starch.

A first growth of Napier grass was hand-harvested under rainy conditions (8.6\% DM, 67.6\% NDF), chopped to $3 \mathrm{~cm}$, treated with $4 \%$ molasses and/or $15 \%$ defatted rice bran (2.0\% crude fat) on the fresh grass basis and ensiled in plastic bags. DM contents of silages were $13.4 \%, 20.1 \%$ and $22.5 \%$ and spoilage losses were $5.6 \%$, $0.3 \%$ and $3.0 \%$ for treatments with molasses, rice bran and their mixture, respectively. Treatment with plain rice bran had the highest content of acetic (6.7\% of DM) and propionic (1.4\% of DM) acids and ammonia- $\mathrm{N}$ but the lowest content of lactic acid. The authors [76] concluded that the combination molasses/rice bran can improve the fermentation quality and enhance the utilization of the silage by goats, more than each additive as a single treatment.

Cassava (Manihot esculenta) tuber meal (72.1\% WSC) and coconut (Cocos nucifera) oil meal (17.6\% WSC) were both added (5\% wet basis) to Guinea-A (Panicum maximum) with $17.7 \%$ DM and $6.3 \%$ WSC and to NB-21 (Pennisetum purpureumx Pennisetum americanum) with 16.3\% DM and 9.9\% WSC forages, chopped $(1.5 \mathrm{~cm})$ and ensiled in $2 \mathrm{~kg}$ laboratory silos. Both additives improved fermentation as compared to untreated silages of both forages, with greater effects in silages with cassava tuber meal [77].

Elephant grass was harvested at 75 days growth (19.4\% DM, 72\% NDF) and ensiled in $300 \mathrm{~kg}$ asbestos/cement containers either unwilted or wilted (29.6\% DM) both materials with or without $8 \%$ ground sorghum grain $(\mathrm{w} / \mathrm{w})$. Wilting was achieved by exposing crushed forage stems three hours in windrow after harvesting with a 
mower/conditioner (New Holland). Sorghum addition to both wilted and unwilted silage increased DM contents, reduced ethanol and acetic acid contents and increased intake of digestible energy as measured in sheep [78].

Silages of elephant grass cv. Guaçu were obtained adding $0 \%, 8 \%, 16 \%$ and $24 \%(\mathrm{w} / \mathrm{w})$ either of ground ear corn with husks, wheat bran or "saccharin" (urea treated sugar cane, with $12.6 \%$ crude protein, $17.5 \%$ crude fibre in DM) to unwilted forage (12.40\% DM, 10.4\% WSC) harvested with a precision chopper (3 mm chop length) and packed into 200 l plastic containers with a layer of ground hay at the bottom to absorb effluent [79]. Ground ear corn was more effective to increase DM content and to restrict lactic acid production while reducing ammonia-N which reached $31.3 \%$ and $36.2 \%$ for "sacharin" and wheat bran treatments, respectively [79].

The fermentation pattern of wilted elephant grass cv. Taiwan-A146 silage (8 hour wilting, 26.6\% DM, 6.74\% WSC) did not differ from silages made of unwilted grass (23.5\% DM, 7.2\% WSC) prepared with a cassava starch by-product added at $2 \%, 4 \%, 8 \%$ or $12 \%(\mathrm{w} / \mathrm{w})$. According to the authors [80] the relatively low lactic acid levels demonstrate that the substrate was not available to lactic acid bacteria.

\section{4) Citrus Pulp}

Fresh citrus peels have been added at the ensilage of Napier grass with levels up to $50 \%$ improving fermentation quality as measured by low pH values and low butyric acid content and adequate lactic acid production [81]. Citrus peels may contain 50\% WSC in DM but the low DM content (14\% - 21\%) and intensive initial fermentation lead to high seepage losses causing a serious pollution problem [82].

Dried citrus pulp added at the ensilage to low DM forages may increase its weight by $145 \%$ by absorbing excessive moisture thus preserving nutrients which otherwise would be lost by effluent and uncontrolled fermentation [83]. The DM, WSC and fermentation acids content of elephant grass silage was increased whilst pH was reduced with the use $0 \%, 5 \%, 10 \%, 15 \%$, and $20 \%$ of dried citrus pulp [81]. Levels up to $30 \%$ of dried ground citrus pulp were added to a 75 days regrowth of elephant grass resulting in silages with a corresponding linear increase of DM content $(y=0.49 x+24.0)$, a $\mathrm{pH}$ in a range from 3.49 to 3.68 and a linear decrease of ammonia-N [84]. Dried pulps such as sugar beet pulp and citrus pulp additives had a good results used as nutrients or absorbents [7].

\subsubsection{Acids}

Acids are added to forages at ensiling to cause an immediate drop in $\mathrm{pH}$ or to increase bunk life. Formic acid and mineral acids (sulfuric and hydrochloric) added at 10 - $30 \mathrm{lbs} /$ wet ton will reduce $\mathrm{pH}$ quickly and greatly limit fermentation losses of protein and carbohydrates. Mineral acids are recommended the rapid acidification of the crop with a pH of about 3.5, which was originally thought to inhibit microbial and plant enzyme activity [85]. When acids are added, plant materials sink quickly and are easy to consolidate. Acidity may arrest plant respiration and reduce heat production and nutrient loss. Rapid acidification may also inhibit clostridia. However, addition of acids increases effluent and can be potentially toxic to animals. Furthermore, acids are corrosive to people, animals and machinery. Reduction of moisture content may minimize effluent, and addition of calcium carbonate can be used to adjust silage acidity. According to [85] appropriate concentrations of different acids as silage additives are recommended as follows:

- sulphuric and hydrochloric acids: 50 - 80 litre of dilute acid (concentrated acid diluted with water at 1:5 v/v) per tonne

- formic acid: about $3 \mathrm{~kg} / \mathrm{ton}$

- acetic acid: 5 - $20 \mathrm{~kg} / \mathrm{ton}$

- propionic acid: 1 litre $/ \mathrm{m}^{2}$ of surface to prevent mould development.

\section{1) Formic Acid and/or Formaldehyde Treatments}

Commercial formic acid (85\%) has been extensively used for the ensilage of unwilted temperate grasses but is gradually being substituted by biological additives, certainly because it is unsafe in handling and application and corrosive to equipment. Information about the use of such additives on tropical forages is limited to research data and no literature was found reporting farm-scale adoption.

Earlier studies by [69] with the production of young, high-protein, low WSC and DM elephant grass have shown that a $0.8 \%$ rate of formic acid is needed for a reasonably good silage fermentation, while [86] found no effectiveness based on silage composition when applying formic acid at various rates to unwilted or wilted elephant grass. On the other hand $0.5 \%$ formic acid treated elephant grass had not only an improved fermentation but also higher intake and digestibility as compared to the untreated control [70].

King grass (Pennisetum purpureum $\times$ Pennisetum typhoides) silage treated with formic acid (3.5 l/t) showed 
better fermentation quality than benzoic acid treated and untreated silages [87]. In a review by [59] on the use of mineral or organic acids as well as of antimicrobials it is concluded that for the ensilage of tropical forages kind of additive and application rate need to be determined specifically according to the type of forage.

Formalin (35\% - 40\% formaldehyde solution) has also been used as a silage preservative, especially aiming at reduced protein degradation in the silo and thus increasing undegradable protein in the rumen of silage-fed animals. Formaldehyde restricts considerably fermentation of silage; $0.8 \%$ formalin (w/w fresh basis) almost sterilizes the ensiled mass of elephant grass and reduces digestibility of silage [69]. A doses of $0.5 \%$ formalin (w/w) applied to a mixture of elephant grass with cassava tops (20.3\% DM, 8.5\% WSC) reduced ammonia-N and increased precipitable protein in silage, however without suppressing a clostridial fermentation [88]. Studies with a $70 \%$ formalin plus $26 \%$ formic acid plus $4 \%$ water mixture applied $0.2 \%(\mathrm{w} / \mathrm{w})$ to elephant grass $(13 \% \mathrm{DM})$ aiming at a rate of $4 \mathrm{~g}$ formaldehyde/100g crude protein in forage resulted in poor fermentation quality and impairment of nutritive value of silages produced. Accurate formaldehyde rates necessary to improve fermentation in the silo as well as to obtain a protein protection effect in the rumen are difficult to achieve especially under farm-scale conditions [89].

\section{2) Propionic Acid}

It is the short-chain fatty acids; propionic acid has the greatest antimycotic activity. It is weaker than formic and mineral acids, but can be a useful additive for silages. Propionic acid is effective in reducing yeast and molds which are responsible for aerobic deterioration in silages. The antimycotic effect of propionic acid is enhanced as $\mathrm{pH}$ declines, making it an ideal candidate for improving the aerobic stability of corn silage where $\mathrm{pH}$ is low. In the past, aerobic stability was improved when large amounts of propionic acid ( $1 \%$ to $2 \%$ of the DM) were added to silage, but the high percentage of acid often restricted fermentation in these cases. The application rate of propionic acid additives has varied depending on moisture content of the forage, length of storage and formulation with other preservatives. For example, Adding 30 - 40 lbs. propionic acid/wet ton of hay crop silage increases its bunk life and reduces surface molding. Low DM silage needs more propionic acid than does drier silage. On wilted silage, $30 \mathrm{lbs}$. propionic acid/ton significantly decreased aerobic spoilage, but $100 \mathrm{lbs}$./ton was needed when the silage had $30 \%$ dry matter. For high moisture corn with a moisture content of $20 \%$ the application rate should be $0.1 \%$ and $0.5 \%$ for storage of 1 and 6 months, respectively, while it should be increased to $0.8 \%$ and $1.1 \%$ for $30 \%$ moisture of silage for the corresponding lengths of storage. Application rates of $1.5 \%$ to $2.0 \%$ for haylage and $2.0 \%$ to $2.5 \%$ for haylage with less than $30 \%$ of DM have been suggested. For corn silage, propionic acid at usage rates of $0.2 \%$ to $0.5 \%$ have been shown to be effective [90]. Many current products that are added to forage at ensiling for the purpose of improving aerobic stability contain several ingredients including benzoic acid, sorbic acid, and citric acid; however, propionic acid usually constitutes the greatest percentage of the active ingredients. Recommended application rates of these products are relatively low (2 - $4 \mathrm{lb} /$ ton of fresh forage). Such low application rates usually do not affect silage fermentation but reduce the numbers of spoilage yeasts and improve aerobic stability. In addition, several products have been designed to be added to silages or TMR just prior to feeding to prevent heating and spoiling in the feed bunk. However, different research output suggests that controlling yeasts at the time of ensiling is more efficient than trying to control their numbers and metabolism in the feed bunk.

Propionic acid is difficult to handle because it is corrosive. Thus, the acid salts, e.g., calcium, sodium and ammonium propionate have been used in some commercial products. The efficacy of propionic acid and its salts is closely related to their solubility in water. The stronger the bond is between the acid-base, the less soluble the product is and thereby less effective in inhibiting fungi. Among these salts, ammonium propionate is most soluble in water (90\%), followed by sodium propionate (25\%) and calcium propionate (5\%) [23].

\section{3) Sodium Diacetate}

This is mixture of acetic acid and its sodium salt. Recommended rate of application is 1 - 2 lbs. active ingredient/ton of wet silage. This compound produces results similar to propionic acid and is quite effective in reducing top spoilage. Adding sodium diacetate at the recommended rate to just the last few loads of forage going into the silage is effective in reducing top spoilage. The same scheme will probably work for propionic acid products. In both cases, the top of the silage mass must be covered with plastic immediately after filling for the compound to work. By just treating the last few loads, treatment costs are reduced considerably.

\subsubsection{Nutrient Additives}

1) Ammonia and Urea 
Anhydrous ammonia or water- or molasses-ammonia mixes have been used as silage additives. Ammonia additions have resulted in a) addition of an economical source of crude protein [91]; b) prolonged bunk life during feeding (aerobic stability, [92]); c) less molding and heating during ensiling; and d) decreased protein degradation in the silo [93]. Urea has been added to corn silage as an economical source of crude protein. However, a beneficial effect of urea on improved bunk life and decrease in proteolysis has not been totally substantiated. Whenever ammonia or urea is added to the diet, special attention should be made to ensure that degradable and undegradable protein requirements are balance for the target ruminant animal.

Ammonia has been used to treat corn silage, small cereal grain silage and high moisture corn with varying degrees of success. Although some have used ammonia on alfalfa silage, this practice is not recommended [56]. Addition of anhydrous ammonia or water-ammonia mixes initially buffers the plant material. For example, corn forage may have a $\mathrm{pH}$ of 5.9 but treated corn forage will have a $\mathrm{pH}$ of about 8.5 to 9.0. When fermentation in the silo is complete, corn silage treated with anhydrous ammonia usually is $0.1-0.2$ units higher in $\mathrm{pH}$, contains $0.5 \%$ - 1.5\% (DMB) more lactic acid, 0.5\% - 1.5\% more acetic acid, and less residual water soluble carbohydrates. Forages treated with ammonia have also been shown to be higher in insoluble $\mathrm{N}$ and true protein [94] primarily because ammonia reduces plant proteolysis. Although fermentation is generally stimulated by ammonia, the ensiling processes is prolonged because of ammonia buffering effect resulting in greater total acid production and inconsistent effects on DM recovery. [95] reported that use of anhydrous ammonia had adverse effects on DM recovery, particularly in high moisture sorghum silage.

Ammonia can be added at the chopper, blower, bagger or bunk. Mixed ammonia solutions are bulkier than anhydrous ammonia but retention of ammonia is usually greater. In addition, molasses (to improve palatability and fermentation) and minerals can be added in these solutions. Some ammonia will be lost (between $10 \%$ and $30 \%$ ) and losses will be greater if ammonia is not applied properly and if forage becomes too dry. Ammonia should be applied to the forage before it contacts the blower to minimize losses. Ammonia should be added at the end nearest the cutter in a chopper with an auger system. If no auger is used, ammonia can be added behind the cutter prior to entering the blower. Ammonia can also be spiked into bunks between loads and it will disperse into the mass. Application of anhydrous ammonia should be at approximately 6 to $7 \mathrm{lb}$ of $\mathrm{N}$ per $700 \mathrm{lb}$ of forage DM. This will increase crude protein from about $8 \%$ to $12.5 \%$ on a dry matter basis. Excess ammonia (12 - $15 \mathrm{lb}$ per ton) may result in poor fermentation (because of a prolonged buffering effect) and animal performance. Using the Cold-flo method is the simplest way to add ammonia to silage. Gaseous ammonia is super cooled in a converter box and about $80-85 \%$ becomes liquid.

Anhydrous ammonia should not be added to corn forage if the DM content is above $40 \%-42 \%$ because fermentation is restricted in drier material and binding of ammonia will be less; thus normal fermentation may be disrupted. In instances where forage DM is above $40 \%-42 \%$, water-ammonia mixes or molasses-ammonia mixes should be used. Application for molasses-ammonia mixes should be as recommended by the manufacturer.

Ammonia is a hazardous gas and should be handled with care. Eye protection should be worn when making connections to pressurized tanks. Water should be available at all times. Ammonia is also corrosive to zinc, copper and brass. Therefore storage of ammonia-treated forage in zinc coated steel silos is not recommended.

Addition of ammonia to corn silage has no effect on nitrate levels in corn silage [96]. Urea and ammonia can improve the aerobic stability of silage [7] [97].

Such additives as particularly urea when added to high dry matter, low buffering forages (maize or sorghum grain) increase crude protein content and are claimed to improve aerobic stability of silage at feedout. In a report by [97] on the use of urea as a silage additive for elephant grass it was concluded that with low DM forage and in the absence of additives rich in WSC such type of product should not be recommended when aiming an improvement of fermentation. Generally, $\mathrm{pH}$ value, ammonia- $\mathrm{N}$ and acetic and butyric acid contents are increased. [98] registered the highest $\mathrm{pH}$ values and ammonia-N levels associated to higher anaerobic proteolytic bacterial populations in Sorghum bicolor silages (34\% DM) made with $0.5 \%$ urea. Other NPN sources as ammonium sulfate and biuret, either alone or associated with urea, calcium carbonate or starch sources have also been tested on their effects on silage fermentation, digestibility and intake. The results as reported by [86] do not favour their use as silage additives either. According to [95] NPN always acts as a buffer during fermentation, requiring extra lactic acid to be produced to lower the $\mathrm{pH}$ enough for preservation, thus increasing DM loss.

\section{2) Minerals}

Minerals such as calcium, phosphorous, sulfur and magnesium have been added to forage at the time of en- 
siling. Usually these either have no effect on fermentation or act as buffers resulting in higher $\mathrm{pH}$ silage. The only reason for adding minerals at the time of ensiling is if the silage will be the only feed offered to the animals. Addition of minerals will make the silage more nutritionally complete. If concentrates are going to be supplemented, it is better to add the minerals to the concentrate mix [66]. Salt is also a mineral additive. The addition of $1 \%$ sodium chloride to a mixture of wilted elephant grass and cassava tops (28\% DM, 9.5\% WSC) was not effective to improve fermentation of silage as compared to the unwilted control [88].

\section{Conclusion}

To ensure good animal health and growth, it is essential to produce feed having high nutritive value and microbiological quality. Silage additives can be useful tools to improve silage quality (increase nutritional content) and animal performance (milk [quantity and/or composition], gain, body condition, reproduction), or decrease heating and molding during storage and fadeout; however, they are not replacements for good management practices. Silage additives will not make poor quality forage in to good but they can help make good quality forage into excellent quality silage. Silage additives can be beneficial and economical to use. Producers should use silage additives that are supported with published data. Microbial inoculants have improved the nutritive value of silages, but enzymes have been inconsistent. Effects of microbial inoculants on aerobic stability have also been inconsistent. Anhydrous ammonia and propionic acid can improve the aerobic stability of silages, but their use is not widespread due to difficult handling and cost, respectively. To make the best silage always use an additive is a good recommendation if care should be taken when choosing a silage additive and follows the product's direction properly.

\section{References}

[1] Zehra Sariçiçek B. and Ünal KILIÇ (2009) The Effects of Different Additives on Silage Gas Production, Fermantation Kinetics and Silage Quality. Ozean Journal of Applied Sciences, 2, 1943-2429.

[2] Lattemae, P., Laats, A. and Tamm, U. (2006) The Technological Factors Affecting the Quality of Big Bale Silage. www.eria.ee/public/files/summary_1.8_2006./link/

[3] Haigh, P.M. (1988) The Effect of Wilting and Silage Additives on the Fermentation of Autmn Made Grass Silage Ensiled in Bunkers on Commercial Farms in South Wales. Grass and Forage Science, 43, 337-345.

[4] Oliveira, A.S. (1995) Rapid pH Reductions in Silages. Vol. 12, Revista Brasileira de Saúde e Produção Animal, Salvador, 1-5.

[5] Merry, R.J., Cussen-MacKenna, R.F., Williams, A.P. and Tweed, J.K.S. (1993) The Effect of Different Inoculants on Fermentation and Proteolysis in Silages of Differing Perennial Ryegrass and White Clover Content. Proceedings of the 10th International silage Conference, Dublin, 6-8 September 1993, 83.

[6] Kenilworth and Warwickshire (2012) Silage Additives. Dairy Co. Agriculture and Horticulture Development Board, Stoneleigh Park.

[7] McDonald, P., Henderson, A.R. and Heron, S.J.E. (1991) The Biochemistry of Silage. 2nd Edition. Chalcombe Publications, Marlow, Bucks.

[8] Stewart, W.M. (2011) Plant Nutrition Today. From Scientific Staff of the International Plant Nutrition Institute (IPNI), Norcross, Georgia.

[9] Meeske, R. (2005) Silage Additives: Do They Make a Difference? Vol. 6, Department of Agriculture Western Cape, Elsenburg,X1, SA-ANIM SCI 2005, South Africa.

[10] Weissbach, F. and Honig, H. (1996) Uber die Vorhersage und Steuerung des Garungsverlaufs bei der Silierung von Grunfutter aus extensivem Anbau. Landbauforschung Volkenrode, 1, 10-17.

[11] Jonsson, A. (1991) Growth of Clostridium Tyrobutyricum during Fermentation and Aerobic Deterioration of Grass Silage. Journal of the Science of Food and Agriculture, 54, 557-568.

[12] Muck, R.E. (1996) A Lactic Acid Bacterial Strain to Improve Aerobic Stability of Silages. In: 1996 Research Summaries, US Dairy Forage Research Center, Madison, 42-43.

[13] Pitt, R.E. and Leibensperger, R.Y. (1987) The Effectiveness of Silage Inoculants: A Systems Approach. Agricultural Systems, 25, 27-49.

[14] Ruser, B. (1989) Das vorkommen von lactobacterien auf futterpflanzen. Landbauforschung Völkenrode, 39, 32-39.

[15] Spoelstra, S.F. and Hindle, V.A. (1989) Influence of Wilting on Chemical and Microbiological Parameters of Grass Relevant to Ensiling. Netherlands Journal of Agricultural Science, 37, 355-364. 
[16] Rooke, J.A. (1990) The Numbers of Epiphytic Bacteria on Grass at Ensilage on Commercial Farms. Journal of the Science of Food and Agriculture, 51, 525-533. http://dx.doi.org/10.1002/jsfa.2740510409

[17] Pahlow, G. and Honig, H. (1996) The German Silage Additive Approval Scheme. Proceedings of the 11th International Silage Conference, Aberystwyth, 8-11 September 1996, 146-147.

[18] Muck, R.E. (1989) Initial Bacterial Numbers on Lucerne Prior to Ensiling. Grass and Forage Science, 44, 19-25. http://dx.doi.org/10.1111/j.1365-2494.1989.tb01905.x

[19] Henderson, N. (1993) Silage Additives. Animal Feed Science and Technology, 45, 35-56. http://dx.doi.org/10.1016/0377-8401(93)90070-Z

[20] Merensalmi, M. and Virkki, M. (1991) The Role of Enzymes in the Preservation and Utilization of Forage. Proceedings of 5th International Symposium on Forage Preservation, Nitra, January 1991, $43-46$.

[21] Kaiser, A.G. (1999) Silage Additives. Department of Primar Industries, Wagga Wagga Agricultural Institute, Wagga Wagga, NSW.

[22] Bolsen, K.K., Bonilla, D.R., Huck, G.L., Young, M.A., Hart-Thakur, R.A. and Joyeaux, A. (1996) Effect of a Propionic Acid Bacterial Inoculant on Fermentation and Aerobic Stability of Whole-Plant Corn Silage. Journal of Animal Science, 74, 274.

[23] Kung Jr., L., (2010) A Review on Silage Additives and Enzymes. Department of Animal and Food Sciences University of Delaware Newark, DE 19717-1303.

[24] Kung Jr., L. and Muck, R.E. (1997) Animal Response to Silage Additives. Proceedings from the Silage: Field to Feedbunk North American Conference, Hershey, 11-13 February 1997, NRAES-99, 200-210.

[25] Kung Jr., L. and Muck, R.E. (1997) Effects of Silage Additives on Ensiling. Proceedings from the Silage: Field to Feedbunk North American Conference, Hershey, 11-13 February 1997, NRAES-99, 187-199.

[26] Staudacher, W., Pahlow, G. and Honig, H. (1999) Certification of Silage Additives in Germany by DLG. Proceedings of 12th International Silage Conference, 5-7 July 1999, Uppsala, 239-240.

[27] Spoelstra, S.F. (1985) Nitrate in Silage. A Review. Grass and Forage Science, 40, 1-11. http://dx.doi.org/10.1111/j.1365-2494.1985.tb01714.x

[28] Kaiser, E. and K. Weiss (1997) Fermentation Process during the Ensiling of Green Forage Low in Nitrate. 2. Fermentation Process after Supplementation of Nitrate, Nitrite, Lactic-Acid Bacteria and Formic Acid. Archives of Animal Nutrition, 50,187-200.

[29] Cheng, Y., Chen, C. and Peng, P. (2001) Effects of Different Additives on Silage Quality of Napiergrass. Proceedings of the 19th International Grassland Congress, San Pedro, 11-21 February 2001.

[30] Bolsen, K.K., Sonon, R.N., Dalke, B., Pope, R., Riley, J.G. and Laytimi, A. (1992) Evaluation of Inoculant and NPN Silage Additives: A Summary of 26 Trials and 65 Farm-Scale Silages. Kansas State University, Manhattan.

[31] Gordon, F.J. (1989) An Evaluation through Lactating Cattle of a Bacterial Inoculant as an Additive for Grass Silage. Grass and Forage Science, 44, 169-179. http://dx.doi.org/10.1111/j.1365-2494.1989.tb01924.x

[32] Kung Jr., L., Ranjit, N.K., Robinson, J.R. and Charley, R.C. (1999) The Effect of Lactobacillusn buchneri on the Fermentation and Aerobic Stability of Barley Silage. Proceedings of the 12th International Silage Conference, Uppsala, 5-7 July 1999, 272-273.

[33] Rice, D.W., Soderlund, S.D., Phillip, I.E. and Harrison. J.H. (1990) Effect of Microbial Inoculation on Digestibility of Legume Silages. Journal of Dairy Science, 73, 195.

[34] Moran, J.P. and Owen, T.R. (1995) The Effects of Feeding Silage Treated with an Inoculum of Lactobacillus plantarum on Beef Production from Growing and Finishing Cattle. Annales de Zootechnie, 44, 383. http://dx.doi.org/10.1051/animres:199505343

[35] Meeske, R., van der Merwe, G.D., Greyling, J.F. and Cruywagen, C.W. (2003) The Effect of the Addition of a Lactic Acid Bacterial Inoculant to Maize at Ensiling on Silage Composition, Silage Intake, Milk Production and Milk Composition. South African Journal of Animal Science, 32, 263-270.

[36] Meeske, R. and Basson, H.M. (1998) The Effect of a Lactic Acid Bacterial Inoculant on Maize Silage. Animal Feed Science and Technology, 70, 239-247. http://dx.doi.org/10.1016/S0377-8401(97)00066-7

[37] Pitt, R.E. (1990) The Probability of Inoculant Effectiveness in Alfalfa Silages. Transactions of the ASAE, 33, 17711778. http://dx.doi.org/10.13031/2013.31538

[38] Meeske, R., Basson, H.M. and Cruywagen, C.W. (1999) The Effect of a Lactic Acid Bacterial Inoculant with Enzymes on the Fermentation Dynamics, Intake and Digestibility of Digitaria Eriantha Silage. Animal Feed Science and Technology, 81, 237-248. http://dx.doi.org/10.1016/S0377-8401(99)00089-9

[39] Meeske, R. and Basson, H.M. (1998) The Effect of a Lactic Acid Bacterial Inoculant on the Fermentation Dynamics of 
Eragrostis curvula during Ensiling. African Journal of Range and Forage Science, 14, 88-91.

[40] Mayne, C.S. (1990) An Evaluation of Lactobacillus plantarum as an Additive for Grass Silage for Dairy Cattle. Animal Production, 51, 1-13. http://dx.doi.org/10.1017/S0003356100005109

[41] Keady, T.W.J. and Murphy, J.J. (1993) A Comparative Evaluation through Lactating Dairy Cows of Silage Made with a Bacterial Inoculant and Formic Acid from Difficult-to-Ensile Herbage. Proceedings of the 10th International Silage Conference, 6-8 September 1993, Dublin, 226.

[42] Mayne, C.S. (1993) The Effect of Formic Acid, Sulphuric Acid and a Bacterial Inoculant on Silage Fermentation and the Food Intake and Milk Production of Lactating Dairy Cows. Animal Production, 56, 29-42. http://dx.doi.org/10.1017/S0003356100006139

[43] Wilkins, R.J. (1996) Silage Production and Utilization-Perspectives from the Silage Research Conferences. Proceedings of the 11th International Silage Conference, 8-11 September 1996, Aberystwyth, 1-10.

[44] Honig, H. and Daenicke, R. (1993) The Effect of Inoculation with Lactic Acid Bacteria on the Utilization of Maize Silage by Bulls. Proceedings of the 10th International Silage Conference, 6-8 September 1993, Dublin, 129.

[45] Filya, I., Hanoglu, H., Sucu, E. and Karabulut, A. (2002) Ensiling Maize with Biological Additives in Large Containers. Proceedings of the 13th International Silage Conference, 11-13 September 2002, South Ayrshire, 194.

[46] Thaysen, J., Sudekum, K.H., Susenbeth, A., Engelhard, T. and Wulfes, R. (2002) Effects of Lacic Acid Bacteria (Lactobacillus plantarum), Molasses and Their Combination on the Quality of Grass and Maize Silages and the Performance of Dairy Cows. Proceedings of the 13th International Silage Conference, 11-13 September 2002, South Ayrshire, 212.

[47] Filya, I. and Sucu, E. (2002) Effects of Enzyme-Lactic Acid Bacteria Mixture Silage Inoculants on the Fermentation, Aerobic Stability, Cell-Wall Content, and in Situ Rumen Degradability of Wheat, Sorghum and Maize Silages in Turkey. Proceedings of the 13th International Silage Conference, 11-13 September 2002, South Ayrshire, 200.

[48] Meeske, R., van der Merwe, G.D., Greyling, J.F. and Cruywagen, C.W. (2002) The Effect of Adding an Enzyme Containing Lactic Acid Bacterial Inoculant to Big Round Bale Oat Silage on Intake, Milk Production and Milk Composition of Jersey Cows. Animal Feed Science and Technology, 97,159-167. http://dx.doi.org/10.1016/S0377-8401(01)00352-2

[49] Weinberg, Z.G. and Ashbell, G. (1993) Biological Silage Additives-Summary of Experiments in Israel. Proceedings of the 10th International Silage Conference, 6-8 September 1993, Dublin, 26.

[50] Meeske, R., Ashbell, G., Weinberg, Z.G. and Kipnis, T. (1993) Ensiling Fodder Sorghum at Two Stages of Maturity with the Addition of Lactic Acid Bacterial Inoculants. Anim. Animal Feed Science and Technology, 43, 165-175. http://dx.doi.org/10.1016/0377-8401(93)90076-V

[51] Meeske, R. (1998) The Effect of an Inoculant on the Preservation of a Tropical Grass (Eragrostis curvula) and Lucerne (Medicago sativa) in South Africa. In: Lyons, T.P. and Jacques, K.A., Eds., Biotechnology in the Feed Industry, Proceedings of Alltech's Fourteenth Annual Symposium, Nottingham University Press, Nottingham, 145-156.

[52] Seale, D.R., Henderson, A.R., Petterson. K.O. and Lowe, J.F. (1986) The Effect of the Addition of Sugar and Inoculation with Two Commercial Inoculants on the Fermentation of Lucerne Silage in Laboratory Silos. Grass and Forage Science, 41, 61-70. http://dx.doi.org/10.1111/j.1365-2494.1986.tb01793.x

[53] Whiter, A.G., Kung Jr., L., Ranjit, N.K., Tavares, J.Y. and Robinson, J.R. (1999) The Interactions between Silage Dry Matters and Forms of Bacterial Inoculants. Journal of Dairy Science, 82, 125.

[54] Flores-Galaraza, R.O., Glatz, B.A., Bern, C.J. and Van Fossen, L.D. (1985) Preservation of Highmoisture Corn by Microbial Fermentation. Journal of Food Protection, 48, 407-411.

[55] Dawson, T.E. (1994) Propionic Acid-Producing Bacteria as Bioinoculants for the Preservation of Ensiled High-Moisture Corn. Ph.D. Dissertation, Michigan State University, East Lansing.

[56] Kung Jr., L., Craig, W.M. and Satter, L.D. (1989) Ammonia-Treated Alfalfa Silage for Lactating Dairy Cows. Journal of Dairy Science, 72, 2565-2572. http://dx.doi.org/10.3168/jds.S0022-0302(89)79397-8

[57] Allman, J.G. and Stern, L.A. (1999) BiomaxÒ5 Microbial Inoculant for Corn Silage. http://www.chbiosystems.com/new_products/biomax/biomax.html

[58] Dreihuis, F., Spoelstra, S.F., Cole, S.C.J. and Morgan, R. (1996) Improving Aerobic Stability by Inoculation with Lactobacillus buchneri. Proceedings of the 11th International Silage Conference, Aberystwyth, 8-11 September 1996, 106-107.

[59] Ojeda, F. (1993) Conservantes quimicos en la preservacion de ensilajes tropicales. Pastos y Forrajes, 16, $193-200$.

[60] Ridla, M. and Vehida, S. (1998) Effects of Combined Treatment of Lactic Acid Bacteria and Cell Wall Degrading Enzymes on Fermentation and Composition of Rhodes Grass (Chloris gayana Kunth). Asian-Australasian Journal of Animal Sciences, 11, 522-529. 
[61] Sanchez, W.K., Hunt, C.W., Guy, M.A., Pritchard, G.T., Swanson, B.I., Warner, T.B., Higgins, J.M. and Treacher, R.J. (1996) Effect of Fibrolytic Enzymes on Lactational Performance of Dairy Cows. Journal of Dairy Science, 79, 183.

[62] Chiou, P., Hsiou, K., Chao, C. and Bi, Y. (2001) Effects of Aspergillus oryzae Inclusion on Corn Silage Fermentation. Asian-Australasian Journal of Animal Sciences, 14, 1568-1579.

[63] Stokes, M.R. (1992) Effects of an Enzyme Mixture, an Inoculant, and Their Interaction on Silage Fermentation and Dairy Production. Journal of Dairy Science, 75, 764-773. http://dx.doi.org/10.3168/jds.S0022-0302(92)77814-X

[64] Stokes, M.R. and Zheng, S. (1995) The Use of Carbohydrase Enzymes as Feed Additives for Early Lactation Cows. 23rd Biennial Conference on Rumen Function, Chicago, 14-16 November 1995, 35.

[65] Zheng, S. and Stokes, M.R. (1997) Effects of Fibrolytic Enzymes on Feed Stability and Performance of Lactating Cows. Journal of Animal Science, 75, 278.

[66] Weiss, B. and Underwood, J. (2009) Silage Additives. Ohio State University Extension Department of Horticulture and Crop Science, Columbus.

[67] Woolford, M.K. (1984) The Silage Fermentation. Marcel Decker, New York.

[68] Keady, T.W.J. (1996) A Review of the Effects of Molasses Treatment of Unwilted Grass at Ensiling on Silage Fermentation, Digestibility and Intake, and on Animal Performance. Irish Journal of Agricultural and Food Research, 35, 141.

[69] Boin, C. (1975) Elephant (Napier) Grass Silage Production Effect of Additives on Chemical Composition, Nutritive Value and Animal Performance. Ph.D. Thesis, Cornell University, Ithaca, 215 p.

[70] Silveira, A.C., Tosi, H., de Faria, V.P. and Spers, A. (1973) Efeito de diferentes tratamentos na digestibilidade in Vitro de silagens de capim Napier. Reunião da Sociedade Brasileira de Zootecnia, 2, 217-226.

[71] Tosi, H., Rodrigues, L.R., De, A., Jobim, C.C., et al. (1995) Ensilagem do Capim-Elefante cv. Mott sob diferentes tratamentos. Reunião da Sociedade Brasileira de Zootecnia, 24, 909-916.

[72] Nayigihugu, V., Kellogg, D.W., Johnson, Z.B., Scott, M. and Anschutz, K.S. (19950 Effects of Adding Levels of Molasses on Composition of Bermudagrass (Cynodon dactylon) Silage. Journal of Animal Science, 73, 200.

[73] Esperance, M., Ojeda, F. and Cáceres, O. (1985) Estudio sobre la conservacion de la guinea likoni (Panicum maximum Jacq.) como ensilaje. Pastos y Forrajes, 8, 127-141.

[74] Sibanda, S., Jingura, J.M. and Topps, J.H. (1997) The Effect of Level of Inclusion of the Legume Desmodium uncinatum and the Use of Molasses or Ground Maize as Additives on the Chemical Composition of Grass- and Maize-Legume Silages. Animal Feed Science and Technology, 68, 295-305. http://dx.doi.org/10.1016/S0377-8401(97)00049-7

[75] Jones, D.J.H. (1988) The Effect of Cereal Incorporation on the Fermentation of Spring- and Autumn-Cut Silages in Laboratory Silos. Grass and Forage Science, 43, 167-172. http://dx.doi.org/10.1111/j.1365-2494.1988.tb01884.X

[76] Yokota, H., Fujii, Y. and Ohshima, M. (1998) Nutritional Quality of Napier Grass (Pennisetum purpureum Schum.) Silage Supplemented with Molasses and Rice Bran by Goats. Asian-Australasian Journal of Animal Sciences, 11, 697701.

[77] Panditharatne, S., Allen, V.G., Fontenot, J.P. and Jayasuriya, M.C.N. (1986) Ensiling Characteristics of Tropical Grasses as Influenced by Stage of Growth, Additives and Chopping Length. Journal of Animal Science, 63, 197-207.

[78] Alberto, G., Portela, J.S. and De Oliveira, O.L.P. (1993) Efeito da adição de grão de sorgo moído e do murchamento sobre a qualidade da silagem de Capim-Elefante (Pennisetum purpureum Schum.). Revista da Sociedade Brasileira de Zootecnia, 22, 1-11.

[79] Andrade, J., de, B. and Lavezzo, W. (1998) Aditivos na ensilagem do capim-elefante. I. Composição bromatológica das forragens e das respectivas silagens. Pesquisa Agropecuária Brasileira, 33, 1859-1872.

[80] Ferrari Jr., E., Lavezzo, W., Vieira, M.P. and Lenut, A.L. (1999) Silagem de Capim-Elefante (Pennisetum purpureum, Schum.) emurchecido ou acrescido de farelo de mandioca. I. Qualidade. Anais da 36a Reunião Anual da Soc. Bras. de Zootecnia, Porto Alegre, 26-30 de julho 1999, Rom, 4 p.

[81] De Faria, V.P., Tosi, H. and Godoy, C.R.M. (1972) Polpa de laranja fresca e seca como aditivo para ensilagem do capim elefante Napier. Solo, 64, 41-47.

[82] Ashbell, G. (1992) Conservation of Citrus Peels by Ensiling for Ruminant Feed. In: Simposio Utilização De Subprodutos Agroindustriais E Resíduos De Colheita Na Alimentação De Ruminantes, EMBRAPA-UEPAE Sao, São Carlos, 189-190.

[83] Vilela, D. (1998) Aditivos para silagem de plantas de clima tropical. In: Wechsler, F.S., Ed., Simpósio sobre aditivos na produção de ruminantes e Não-Ruminantes. Anais dos Simpósios, XXXV Reunião da SBZ, 73-108.

[84] Evangelista, A.R., Silva, L.V., Correia. L.F.A., et al. (1996) Efeito de diferentes níveis de polpa cítrica, como aditivo seco, na ensilagem de capim Napier (Pennisetum purpureum Schum.). Anais da 33 ${ }^{a}$ Reunião Anual da Soc. Bras. de 
Zootecnia, Fortaleza, 21-26 de julho 1996, 354-355.

[85] Liu, J.X. and Guo, J. (2010) Ensiling Crop Residues. Zhejiang University and China National Breeding Stock Import and Export Corporation.

[86] Vilela, D. (1984) Aditivos na ensilagem. Coronel Pacheco, MG: EMBRAPA-CNPGL, Circular Técnica 21, 32 p.

[87] Ojeda, F. and Cáceres, O. (1984) Efecto de los aditivos quimicos sobre el consumo y la digestibilidade de los ensilajes de king grass. Pastos y Forrajes, 7, 409-419.

[88] Zanotelli, F.O. and Mühlbach, P.R.F. (1998) Efeitos de diferentes tratamentos nas características fermentativas de silagens da mistura de Capim-Elefante e parte aérea da mandioca. Reunião da Sociedade Brasileira de Zootecnia, 18, 491-99.

[89] Mühlbach, P.R.F. and Kaufmann, W. (1979) Eiweiss-Verfuegbarkeit von Formaldehyd-behandelter Grassilage beim Wiederkaeuer. Das wirtschaftseigene Futter, 25, 115-132.

[90] Beck, T. (1975) The Effect of Ensiling Agents on Aerobic Deterioration. Das Wirtschaft Futter, 4, 8-12.

[91] Huber, J.T., Foldager, J. and Smith, N.E. (1979) Nitrogen Distribution in Corn Silage Treated with Varying Levels of Ammonia. Journal of Animal Science, 48, 1509.

[92] Britt, D.G. and Huber, J.T. (1975) Fungal Growth during Fermentation and Refermentation of Non-Protein Nitrogen Treated Corn Silage. Journal of Dairy Science, 58, 1666-1671. http://dx.doi.org/10.3168/jds.S0022-0302(75)84765-5

[93] Johnson, C.O.L.E., Huber, J.T. and Bergen, W.G. (1982) Influence of Ammonia Treatment and Time of Ensiling on Proteolysis in Corn Silage. Journal of Dairy Science, 65, 1740-1747. http://dx.doi.org/10.3168/jds.S0022-0302(82)82410-7

[94] Buchanan-Smith, J.G. (1982) Preservation and Feeding Value for Yearling Steers of Whole Plant Corn Ensiled at 28 and 42\% Dry Matter with and without Cold Flow Ammonia Treatment. Can. Journal of Animal Science, 62, 173-180. http://dx.doi.org/10.4141/cjas82-018

[95] Bolsen, K.K. (1999) Silage Management in North America in the 1990s. In: Lyons, T.P. and Jacques, K.A., Eds., Biotechnology in the Feed Industry, Proceedings of the 15th Annual Symposium, Nottingham University Press, Nottingham, 233-244.

[96] Li, X., Hansen, W.P., Otterby, D.E., Linn, J.G. and Kuehn, C.S. (1992) Effect of Additives on Fermentation of Corn Silage Containing Different Amounts of Added Nitrate Nitrogen. Journal of Dairy Science, 75, 1555-1561. http://dx.doi.org/10.3168/jds.S0022-0302(92)77912-0

[97] Glewen, M.J., and Young, A.W. (1982) Effect of Ammoniation on the Refermentation of Corn Silage. Journal of Animal Sciences, 54,713-718.

[98] Singh, A., Edward, J.C., Mor, S. and Singh, K. (1996) Effect of Inoculation of Lactic Acid and Additives on Ensiling M.P. Chari (Sorghum Bicolor). Indian Journal of Animal Sciences, 66, 1159-1165. 